\title{
Effects of the Long-effect Additive (NAM), Dicyandiamide (DCD), and Organic C Additions on $\mathrm{N}$ Transformation in Soil
}

\author{
Shaobo Fan, Wantai Yu* \\ Institute of Applied Ecology \\ Chinese Academy of Sciences \\ Shenyang 110016, PR China \\ *Corresponding author
}

\begin{abstract}
A 30-day incubation experiment was conducted to investigate the effects of a long-effect additive (NAM), dicyandiamide (DCD), and glucose additions on $\mathbf{N}$ transformation in soil. The results showed that both NAM and DCD enhanced $\mathbf{N}$ transformation into soil microbial biomass $\mathbf{N}$ and fixed NH4+. Glucose addition enhanced transformation of $\mathbf{N}$ into soil microbial biomass $\mathrm{N}$, consequently decreased soil mineral $\mathrm{N}$ and fixed $\mathrm{NH4}+$ At the end of the incubation, NAM favored to increase soil mineral $N$, indicating the higher availability of $N$. Overall, our research identified that $N$ can be stabilized in soil by the processes of microbial immobilization and mineral fixation, which were enhanced with the addition of NAM and DCD, reducing $N$ losses and remaining $N$ availability, especially for NAM. Although organic $C$ addition increased microbial immobilization of $N$, the availability of $N$ was significantly lowered. Therefore, the rate and time of organic $\mathrm{C}$ application should be regulated to optimize $\mathrm{N}$ management practices.
\end{abstract}

Keywords-NAM; DCD; urea; soil microbial biomass N; fixed $\mathrm{NH}_{4+} ;$ glucose

\section{INTRODUCTION}

Nitrogen $(\mathrm{N})$ is the most important essential nutrient for plant growth, and synthetic $\mathrm{N}$ has become the primary $\mathrm{N}$ source for increasing and maintaining agricultural production [1]. However, overapplication of synthetic $\mathrm{N}$ results in low $\mathrm{N}$ use efficiency, and high $\mathrm{N}$ losses through volatilization as $\mathrm{NH}_{3}$, leaching as $\mathrm{NO}_{3}^{-}, \mathrm{NO}_{2}^{-}$and dissolved organic $\mathrm{N}$, nitrification/denitrification as $\mathrm{N}_{2}$ and $\mathrm{N}_{\mathrm{x}} \mathrm{O}$ emission [2]. These induce both serious environmental problems and severe economic loss [3].

Various approaches could be used to reduce $\mathrm{N}$ losses and increase $\mathrm{N}$ use efficiency in agricultural production, such as optimizing application method of $\mathrm{N}$ fertilizer, combining of synthetic and organic fertilizers, and incorporating crop rotation strategies in cropping systems [2]. One approach is using $\mathrm{N}$ transformation process inhibitors, i.e. urease inhibitors (UIs), nitrification inhibitors (NIs), and combination of them [4]. The inhibitors delay the bacterial oxidation of ammonium (NIs) or the hydrolysis of urea (UIs), increasing or prolonging the mineral $\mathrm{N}$ in its cationic form, which favored its retention by microbial immobilization and mineral fixation in soils $[5$, 6].
The long-effect additive (NAM), which was developed by Institute of Applied Ecology, Chinese Academy Sciences, integrated synergic functions of urease inhibitor and nitrification inhibitor [7]. The effect of NAM on $\mathrm{N}$ transformation was investigated in present study, compared with that of nitrification inhibitor dicyandia mide (DCD).

\section{MATERIALS AND METHODS}

\section{A. Soil Sampling}

The test soil was an Alfisol, and the type of clay mineral was mainly 2:1 clay minerals (TABLE I). Soil sample (0-10 $\mathrm{cm}$ ) was collected fro $\mathrm{m}$ the treatment receiving phosphorus $(\mathrm{P})$ and potassium $(\mathrm{K})$ fertilizers from 1990 at the Shenyang Experimental Station of the Institute of Applied Ecology [8]. The annual application rates of $\mathrm{P}$ and $\mathrm{K}$ in forms of triple super phosphate and potassium sulfate were $25 \mathrm{~kg} \mathrm{P} / \mathrm{ha}$ and $60 \mathrm{~kg}$ $\mathrm{K} / \mathrm{ha}$, respectively.

\section{B. Incubation Experiment}

The incubation experiment included seven treatments with eight replications: (1) no addition (CK), (2) added urea-N (U), (3) added urea-N and glucose $(\mathrm{U}+\mathrm{C})$, (4) added urea-N and NAM (NAM), (5) added urea-N, NAM and glucose (NAM+C), (6) added urea-N and DCD (DCD), and (7) added urea-N, DCD and glucose $(\mathrm{DCD}+\mathrm{C})$. Application rates of $\mathrm{N}$ and $\mathrm{C}$ were $190 \mathrm{mg} \mathrm{N} / \mathrm{kg}$ soil and $3228 \mathrm{mg} \mathrm{C} / \mathrm{kg}$ soil, respectively, and those of NAM and DCD were $2.5 \%(\mathrm{w} / \mathrm{w})$ of the urea-N. Soil was sieved $<5 \mathrm{~mm}$ and incubated at $25^{\circ} \mathrm{C}$ in dark. Soil moisture was maintained at $50 \%$ of water-holding capacity. Four replicates were removed on the 8th and 30th days after the experiment started, respectively. Soil $\mathrm{NH}_{4}{ }^{+}-\mathrm{N}$ and $\mathrm{NO}_{3}{ }^{-} \mathrm{N}$ were extracted by $2 \mathrm{M} \mathrm{KCl}$, and the extractions were distilled after the addition of $\mathrm{MgO}$ and Devardas alloy [9]. The extracted soils were air-dried and passed through a 0.15 -mm sieve for the determination of fixed $\mathrm{NH}_{4}{ }^{+}$following the $\mathrm{KOBr}-\mathrm{HF}$ procedures [10]. Chloroform fu migation extraction method was adopted to estimate the amount of soil microbial biomass $\mathrm{N}$ [11].

\section{Data Analysis and Statistics}

Results are presented as the means of the four replicates expressed on an oven-dry weight basis, and analyzed by ANOVA following Duncan's multiple comparisons at the 0.05 
significance level. Statistical analysis was carried out with SPSS 11.0 software package.

TABLE I. PHYSICOCHEMICAL PROPERTIESOF TEST SOIL

\begin{tabular}{|c|c|c|c|c|c|c|c|}
\hline $\begin{array}{c}\text { Organ } \\
\text { ic C }\end{array}$ & $\begin{array}{c}\text { Tot } \\
\text { al N }\end{array}$ & Sand & Silt & Clay & $\begin{array}{c}\text { Fixed } \\
\mathrm{NH}_{4}{ }^{+}\end{array}$ & $\begin{array}{c}\text { Availa } \\
\text { ble P }\end{array}$ & $\begin{array}{c}\text { Availab } \\
\text { le K }\end{array}$ \\
\hline \multicolumn{6}{|c|}{$g / \mathrm{kg}$} & \multicolumn{3}{c|}{$\mathrm{mg} / \mathrm{kg}$} \\
\hline 11.62 & $\begin{array}{c}0.9 \\
9\end{array}$ & $\begin{array}{c}161 . \\
9\end{array}$ & $\begin{array}{c}595 \\
7\end{array}$ & $\begin{array}{c}241 . \\
2\end{array}$ & 168.2 & 18.0 & 105.0 \\
\hline
\end{tabular}

\section{RESULT AND DISCUSSION}

\section{A. Influences of Inhibitors and Glucose Additions on $\mathrm{NH}_{4}{ }^{+}-\mathrm{N}$}

In non-glucose treatments, urea addition significantly increased $\mathrm{NH}_{4}{ }^{+}-\mathrm{N}$ co mpared with the $\mathrm{CK}$ treatment (FIGURE I). On the 8th day, the greatest $\mathrm{NH}_{4}{ }^{+}-\mathrm{N}$ was observed in the DCD treatment, and followed by the U and NAM treatments. This is mainly attributed to the inhibition effect of DCD on nitrification, whereas urease inhibitor containing in NAM decreased $\mathrm{NH}_{4}{ }^{+}-\mathrm{N}$ in the NAM treatment because of the retardation in the hydrolys is of urea [7]. On the 30th day, the contents of $\mathrm{NH}_{4}{ }^{+}-\mathrm{N}$ lowered compared with those on the 8th day, and were significantly higher in the NAM and DCD treatments than in other treatments, because of the existence of nitrification inhibitors [12].

On the 8th day, there was no significant difference in $\mathrm{NH}_{4}{ }^{+} \mathrm{N}$ among the $\mathrm{CK}$ and glucose treatments, owing to microbial immobilization of $\mathrm{NH}_{4}{ }^{+}$with glucose addition. Reference [13] also revealed that glucose addition decreased soil mineral $\mathrm{N}$ and increased soil microbial biomass $\mathrm{N}$. The effects of inhibitors have also been eliminated with glucose addition. Compared with the $\mathrm{CK}$ treatment, the glucose treatments have higher $\mathrm{NH}_{4}{ }^{+}-\mathrm{N}$ on the 30th day, especially for the $\mathrm{NAM}+\mathrm{C}$ and $\mathrm{DCD}+\mathrm{C}$ treatments. This is due to both nitrification inhibition effect and remineralization of immobilized $\mathrm{N}$ [14].

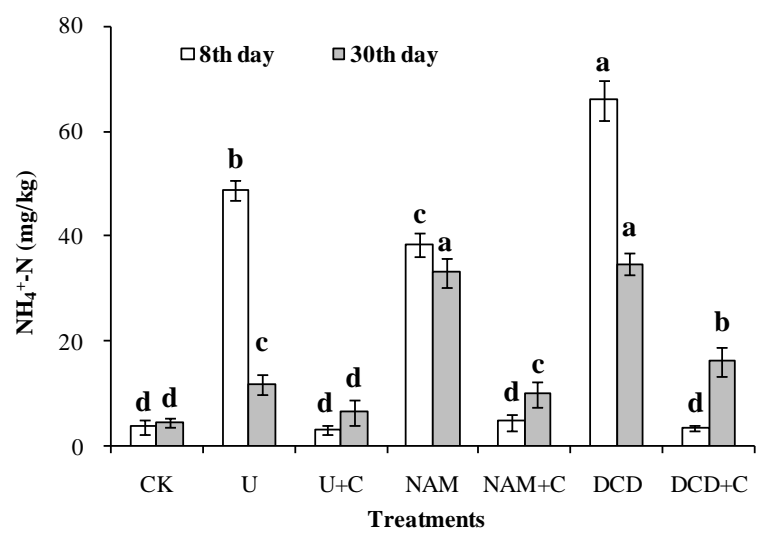

FIGURE I. CONTENT S OF NH4+-N IN DIFFERENT TREATMENT SON THE 8TH AND 30TH DAYS

Note:The same lowercase letter indicates no significant difference bet ween treatments at the same stage $(P<0.05)$. The same as below.

B. Influences of Inhibitors and Glucose Additions on $\mathrm{NO}_{3}{ }^{-} \mathrm{N}$

Addition of urea significantly increased $\mathrm{NO}_{3}{ }^{-} \mathrm{N}$ at different stages in non-glucose treatments , compared with the CK treatment (FIGURE II). On the 8th day, the greatest $\mathrm{NO}_{3}{ }^{-} \mathrm{N}$ was obtained in the $\mathrm{U}$ treatment, and the content of $\mathrm{NO}_{3}{ }^{-} \mathrm{N}$ was significantly lower in the DCD treatment than in the U and NAM treatments, indicating an obvious inhibition effect of DCD on nitrification. Moreover, NAM addition also exhibited the inhibition effect on nitrification to some extent, whereas the inhibition effect of NAM was lower than that of DCD probably because of the different application rates of nitrification inhibitors [4]. Subsequently, the greatest $\mathrm{NO}_{3}{ }^{-} \mathrm{N}$ was achieved in the NAM treatment on the 30th day, and significantly higher than that in the DCD treatment.

In contrast to non-glucose treatments, the contents of $\mathrm{NO}_{3}{ }^{-} \mathrm{N}$ were markedly lowered with the addition of glucose on the 8th day. This phenomenon was primarily attributed to the microbial immobilization for $\mathrm{NH}_{4}{ }^{+}$decreased the $\mathrm{N}$ transformation from the cationic to the anionic [14]. The inhibitors had little effect on the transformation. However, the content of $\mathrm{NO}_{3}{ }^{-} \mathrm{N}$ was significantly higher in the fertilized treatments than in the $\mathrm{CK}$ treatment on the 30th day. In the glucose treatments, the greatest $\mathrm{NO}_{3}{ }^{-} \mathrm{N}$ was obtained in the $\mathrm{NAM}+\mathrm{C}$ treatment, owing to the avoidance of drastic immobilization of fertilizer $\mathrm{N}$ with urease inhibitor input [15].

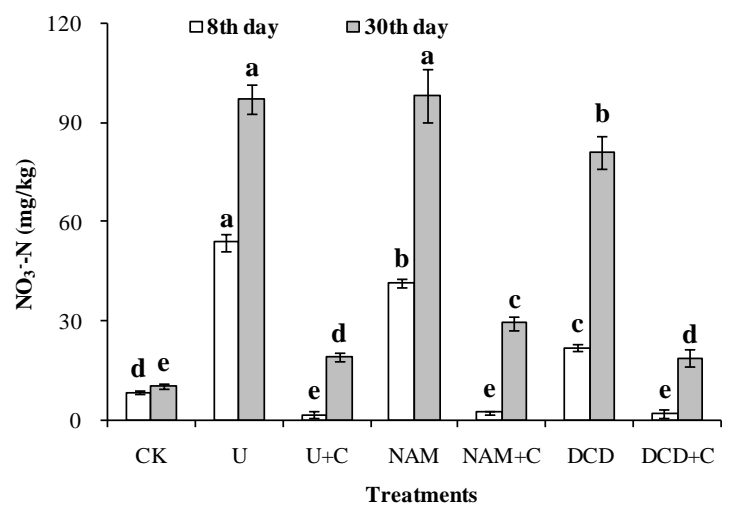

FIGURE II. CONTENT S OF NO3--N IN DIFFERENT T REATMENT S ON THE 8TH AND 30TH DAYS

\section{Influences of Inhibitors and Glucose Additions on Soil Microbial Biomass $N$}

On the 8th day, soil microbial biomass $\mathrm{N}$ significantly increased in fertilized treatments, compared with the CK treatment, and soil microbial biomas $\mathrm{N}$ further increased with glucose addition (FIGURE III). This trend was maintained over the incubation period, with exception for the $U$ treatment on the 30th day. The NAM and NAM+C treatments kept highest levels of soil microbial biomass $\mathrm{N}$ in the non-glucose and glucose treatments, respectively. This was probably attributed to the supply of humic acid with NAM input [7]. DCD also favored to enhance $\mathrm{N}$ immobilization by microorganisms, but the difference was not significantly between the treatment receiving DCD and corresponding treatment without inhibitor. Microbial immobilization is an important process of $\mathrm{N}$ transformation, by which $\mathrm{N}$ can be stabilized in soils [5]. Therefore, additions of NAM and DCD increased soil microbial bio mass $\mathrm{N}$, consequently reduced $\mathrm{N}$ losses. 


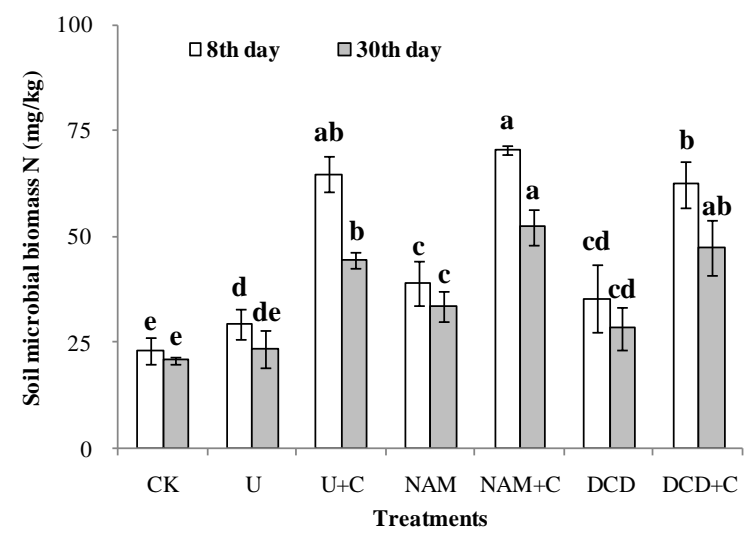

FIGURE III. CONTENT S OF SOIL MICROBIAL BIOMASS N IN DIFFERENT T REATMENT S ONTHE 8TH AND 30TH DAYS

\section{Influences of Inhibitors and Glucose Additions on Fixed $\mathrm{NH}_{4}{ }^{+}$}

Addition of urea markedly increased soil fixed $\mathrm{NH}_{4}{ }^{+}$during the incubation (FIGURE IV). However, the contents of fixed $\mathrm{NH}_{4}{ }^{+}$significantly lowered with glucose addition, because a major portion of $\mathrm{N}$ was converted into organic form [16]. Regardless of the presence of glucose, DCD had significantly influence on increasing fixed $\mathrm{NH}_{4}{ }^{+}$during the incubation due to the greater persistence of applied- $\mathrm{NH}_{4}{ }^{+}$in the soil. The effect of NAM on fixed $\mathrm{NH}_{4}{ }^{+}$was observed at the end of the incubation, owing to the retardation of the hydrolysis of urea and subsequent nitrification inhibition with NAM addition [7]. In conclusion, both NAM and DCD can increase fixed $\mathrm{NH}_{4}{ }^{+}$ pool, by which an available $\mathrm{N}$ pool can be built for crops [17].

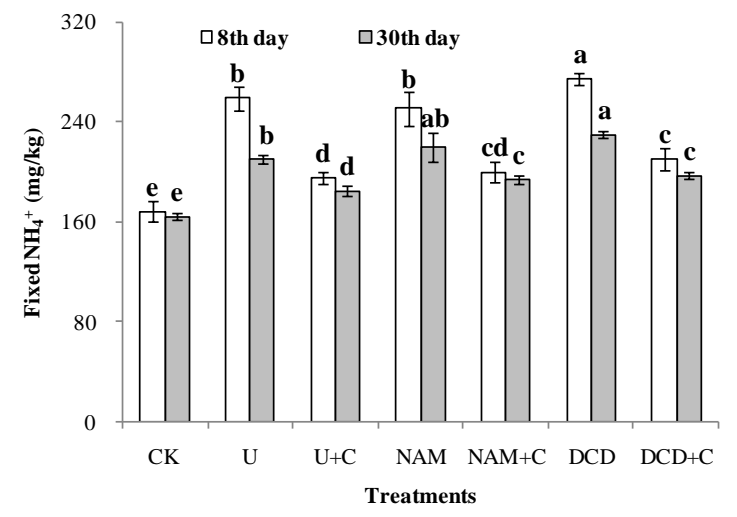

FIGURE IV. CONTENT S OF FIXED NH4+ IN DIFFERENT TREATMENT S ONTHE 8TH AND 30TH DAYS

In general, the greatest mineral $\mathrm{N}\left(\mathrm{NH}_{4}{ }^{+}-\mathrm{N}+\mathrm{NO}_{3}{ }^{-} \mathrm{N}\right)$ was consistently obtained in the NAM and $\mathrm{NAM}+\mathrm{C}$ treatments on the 30th day in corresponding non-glucose and glucose treatment groups, respectively, indicating the higher availability of $\mathrm{N}$ in the treatments containing NAM. Furthermore, both NAM and DCD enhanced N transformation into soil microbial bio mass $\mathrm{N}$ and fixed $\mathrm{NH}_{4}{ }^{+}$pools, stabilizing $\mathrm{N}$ in the soil and reducing $\mathrm{N}$ losses. Although glucose addition enhanced $\mathrm{N}$ microbial immobilization, the availability of $\mathrm{N}$ was significantly lowered. Therefore, the rate and time of organic $\mathrm{C}$ application should be optimized to synchronize $\mathrm{N}$ supply with crop demand.

\section{ACKNOWLEDGMENT}

This work was financially supported by the National Key Technology R\&D Program (No. 2012BAD05B06), and National Natural Science Foundation of China (Nos. 41171242, 41301326).

\section{REFERENCES}

[1] S. H. Chien, L. I. Prochnow, and H. Cantarella, "Recent developments of fertilizer production and use to improve nutrient efficiency and minimize environmental impacts," in Advances in Agronomy, vol. 102, D. L. Sparks, Ed. 2009, pp. 267-322.

[2] Y. Miao, B. A. Stewart, and F. Zhang, "Long-term experiments for sustainable nutrient management in China. A review," Agron. Sustain. Develop., vol. 31, pp. 397-414, 2011.

[3] R. A. Jat, S. P. Wani, K. L. Sahrawat, P. Singh, S. R. Dhaka and B. L. Dhaka, "Recent approaches in nitrogen management for sustainable agricultural production and eco-safety," Arch. Agron. Soil Sci., vol. 58, pp. 1033-1060, 2012.

[4] Y. H. Juan, L. J. Chen, Z. J. Wu and Y. F. Shi, "Effect of urease and nitrification inhibitor on soil-N transformation," Chin. J. Soil Sci., vol. 38, pp. 773-780, 2007.

[5] P. Nannipieri, J. Ascher, M. T. Ceccherini, L. Landi, G. Pietramellara and G. Renella, "Microbial diversity and soil functions," Eur. J. Soil Sci., vol. 54, pp. 655-670, 2003.

[6] R. Nieder, D. K. Benbi and H. W. Scherer, "Fixation and defixation of ammonium in soils: a review," Biol. Fert. Soils, vol. 47, pp. 1-14, 2011.

[7] Y. Q. Feng, D. S. Zhang and Z. Li, "A new way for improving fertilizer efficiency by long-effect additive of compound fertilizers (NAM)," Phosphate Compd. Fert., vol. 22, pp. 41-43, 2007.

[8] Q. Ma, W. Yu, C. Jiang, H. Zhou and Y. Xu, "The influences of mineral fertilization and crop sequence on sustainability of com production in northeastern China," Agric. Ecosyst. Environ., vol. 158, pp. 110-117, 2012.

[9] D. R. Keeney and D. W. Nelson, "Nitrogen-inorganic forms" in Methods of Soil Analysis. Part 2. 2nd ed., A. L. Page and R. H. Miller, Eds. WI. Madison: ASA and SSSA, 1982, pp. 643-709.

[10] J. A. Silva and J. M. Bremner, "Determination and isotope-ratio analysis of different forms of nitrogen in soils: 5. fixed ammonium," Soil Sci. Soc. Am. Proc., vol. 30, pp. 587-594, 1966.

[11] P. C. Brookes, A. Landman, G. Pruden and D. S. Jenkinson, "Chloroform fumigation and the release of soil-nitrogen - a rapid direct extraction method to measure microbial biomass nitrogen in soil," Soil Biol. Biochem., vol. 17, pp. 837-842, 1985.

[12] R. Prasad and J. F. Power, "Nitrification inhibitors for agriculture, health and the environment," in Advances in Agronomy, vol. 54, D. L. Sparks, Ed. 1995, pp. 233-281.

[13] F. Azam, F. W. Simmons and R. L. Mulvaney, "Immobilization of ammonium and nitrate and their interaction with native $\mathrm{N}$ in 3 illinois mollisols," Biol. Fert. Soils, vol. 15,pp. 50-54, 1993.

[14] F. Azam and C. Mueller, "Effect of 3,4-dimethylpyrazole phosphate on some microbial processes in soil," Pak. J. Biol. Sci., vol. 8, pp. 606-613, 2005.

[15] Z. P. Wang, O. Vancleemput, L. Li and L. Baert, "Effect of organic matter and urease inhibitors on urea hydrolysis and immobilization of urea nitrogen in an alkaline soil,” Biol. Fert. Soils, vol. 11, pp. 101-104, 1991.

[16] P. M. Rutherford and N. G. Juma, "Effect of glucose amendment on microbial biomass, spelling fertilizer ${ }^{15} \mathrm{~N}$-recovery and distribution in a barley-soil-system," Biol. Fert. Soils, vol. 12, pp. 228-232, 1992.

[17] Y. L. Liu, B. Zhang, C. L. Li, F. Hu and B. Velde, "Long-term fertilization influences on clay mineral composition and ammonium adsorption in a rice paddy soil," Soil Sci. Soc. Am. J., vol. 72, pp. 1580-1590, 2008. 